\title{
SKRINING AKTIVITAS ANTIMIKROBA EKSTRAK HERBA BELIMBING TANAH (Oxalis corniculata L.) SECARA KLT-BIOAUTOGRAFI DAN DIFUSI AGAR
}

\author{
Herwin, Siska Nuryanti \\ Fakultas Farmasi Universitas Muslim Indonesia \\ Email : herwinfarmasi@gmail.com
}

\begin{abstract}
ABSTARCT
The screening studies have been carried out antimicrobial activity of herb Belimbing Tanah (Oxalis corniculata L.) extracts from Mamuju West Sulawesi that purpose to got data about activity of Belimbing Tanah (Oxalis corniculata L.) extract based on antimicrobial screening of some microbes in the Bioautography-TLC test and agar diffusion. The result screening of antimicrobial activity by BioautographyTLC, showed that dietil eter extract of belimbing tanah (Oxalis corniculata L.) give antimicrobial activity to bacteri Staphylococcus aureus, Streptococcus mutans, Staphylococcus epidermidis, Salmonella thypi, Escherichia coli, Vibrio sp, and fungus Candida albicans with a profile chromatogram using the eluent $n$-hexane: ethyl acetate $R f$ value of 0.45 obtained. And the screening of antimicrobial activity of the juice belimbing tanah (Oxalis corniculata L.) at a concentration of $25 \%, 50 \%$ and $75 \%$ in the diffusion in order to obtain an average diameter of zone of resistance to the bacteria Staphylococcus aureus $=14: 00 \mathrm{~mm}$, Streptococcus mutans $=15.00$ $\mathrm{mm}$, Salmonella thypi $=24.66 \mathrm{~mm}$, Escherichia coli $=19.99 \mathrm{~mm}$, Vibrio $\mathrm{sp}=17.77$ $\mathrm{mm}$, and fungus Candida albicans $=15.00 \mathrm{~mm}$.
\end{abstract}

Keyword : Oxalis corniculata L., Screening of antimicrobial, Mamuju

\section{PENDAHULUAN}

Negara Indonesia mempunyai potensi sumber obat tradisional yang sangat melimpah. Dan kecenderungan masyarakat untuk mencari pengobatan alternatif dengan menggunakan bahan alam, sehingga sekarang ini pengobatan dan pendayagunaan obat tradisional merupakan salah satu komponen program pelayanan kesehatan dasar keberadaan

pengobatan tradisional Indonesia saat ini mulai berkembang yang didukung oleh semakin banyaknya penelitian tentang bahan alam untuk pengobatan tradisional.

Tanaman obat diketahui potensial untuk dikembangkan lebih lanjut pada pengobatan penyakit infeksi, namun masih banyak yang belum dibuktikan bioaktivitasnya 
Skrining Aktivitas Antimikroba Ekstrak Herba Belimbing Tanah Secara KLT-Bioautografi Dan Difusi Agar

secara ilmiah. Salah satu tumbuhan yang sering digunakan oleh masyarakat sebagai obat tradisional adalah belimbing tanah (Oxalis corniculata L.) yang merupakan tumbuhan merayap dari jenis dikotiledon. Tumbuhan ini dapat mengobati beberapa penyakit, antara lain dapat mengatasi penyakit demam, flu, diare, radang hati (hepatitis), radang tenggorokan, infeksi saluran kencing, terlambat haid, hipertensi dan neurasthenia (Setiawan, 2006).

Salah satu ddaerah yang menggunakan belimbing tanah adalah masyarakan Mamuju Sulawesi Barat dimana yang diyakini berkhasiat menyembuhkan penyakit flu dan batuk pada anak-anak. Namun sejauh ini belum ada referensi tentang khasiat dan penggunaannya secara ilmiah. Sehingga dalam rangka pemanfaatannya sebagai bahan obat alam, maka penelitian ini ditujukan skrining aktivitas antimikroba belimbing tanah (Oxalis corniculata L.) terhadap beberapa mikroba uji agar penggunaannya dalam masyarakat lebih dapat dipertanggung jawabkan.

\section{METODE PENELITIAN}

Waktu penelitian dilaksanakan pada bulan Februari 2012 sampai selesai di Laboratorium Mikrobiologi
Fakultas Farmasi Universitas Muslim Indonesia.

Alat dan Bahan, Alat dan bahan yang akan digunakan disiapkan sesuai dengan kebutuhan penelitian.

\section{A. Prosedur Penelitian}

\section{Ekstraksi sampel}

Sampel umbuhan belimbing tanah (Oxalis corniculata L.) diperoleh dari Mamuju, Sulawesi Barat diambil pada jam 10.00 pagi wita. Dibersihkan dari kotorankotoran yang melekat dengan menggunakan air yang mengalir, kemudian dikeringkan dengan cara diangin-anginkan dan tidak terkena sinar matahari langsung.

Bahan berupa belimbing tanah ditimbang sebanyak 100 gram kemudian dimasukkan ke dalam wadah maserasi, lalu ditambahkan etanol 96\% (hingga simplisia tersebut terendam) dan dibiarkan selama 5 hari dengan pengadukan sesering mungkin dalam bejana tertutup dan terlindung dari cahaya. Sampel disaring dan ampasnya direndam lagi dengan cairan penyari yang baru. Hal ini dilakukan hingga proses 
Skrining Aktivitas Antimikroba Ekstrak Herba Belimbing Tanah Secara KLT-Bioautografi Dan Difusi Agar

ekstraksi sempurna. Hasil penyarian yang didapat kemudian diuapkan dengan menggunakan rotavapor hingga diperoleh ekstrak etanol kental dan dipartisi dengan pelarut $n$ heksan, dietil eter.

\section{Penyiapan Suspensi Mikroba}

Mikroba uji hasil peremajaan, masing-masing disuspensikan dengan larutan $\mathrm{NaCl}$ fisiologis $0,9 \%$ dan dimasukkan kedalam kuvet, kemudian diukur transmitannya menggunakan spektrofotometer dengan panjang gelombang 580 $\mathrm{nm}$ pada $25 \%$ untuk bakteri dan $75 \%$ untuk jamur. Sebagai blangko digunakan $\mathrm{NaCl}$ fisiologis 0,9\% steril.

\section{Pengujian}

Skrining

\section{Antimikroba}

\section{a. KLT-Bioautografi}

Ekstrak etanol, heksan, dietil eter dan residu dari belimbing tanah ditimbang sebanyak $10 \mathrm{mg}$ lalu dilarutkan dengan klioroform : methanol (1:1). Setelah larut ditotolkan pada lempeng kromatografi lapis tipis dengan ukuran lempeng untuk masing- masing ekstrak $1 \times 7,5 \mathrm{~cm}$ dan dielusi dengan menggunakan n-heksan : etil asetat (2:1). Setelah terelusi lempeng kromatografi ekstrak etanol, n-heksan, etil asetat dan residu lempeng dikeluarkan dari chamber, diangin-anginkan hingga cairan pengelusinya menguap. Kromatogram yang dihasilkan diamati pada sinar UV panjang gelombang $254 \mathrm{~nm}$ dan 366 $\mathrm{nm}$, serta penyemprotan dengan $\mathrm{H}_{2} \mathrm{SO}_{4} 10 \%$ dan dihitung nilai Rf-nya. Hasil kromatogram diletakkan di atas permukaan medium agar yang telah disuspensi dengan mikroba uji dan dibiarkan selama 60 menit. Setelah itu lempeng tersebut diangkat dan dikeluarkan. Selanjutnya media diinkubasi pada suhu $37^{\circ} \mathrm{C}$ selama $1 \times 24$ jam untuk bakteri dan suhu kamar selama $3 \times 24$ jam untuk jamur.

Hasil skrining aktivitas kromatografi lapis tipis, ekstrak yang memberikan 
Skrining Aktivitas Antimikroba Ekstrak Herba Belimbing Tanah Secara KLT-Bioautografi Dan Difusi Agar

aktivitas dilanjutkan dengan pengujian aktivitas antimikroba secara KLTBioautografi dengan cara media GNA steril sebanyak $10 \mathrm{ml}$ dituang ke dalam cawan petri steril, lempeng kromatografi yang telah dielusi dengan $\mathrm{n}$-heksan : etil asetat (2:1), diletakkan di atas permukaan medium agar yang telah disuspensi dengan mikroba uji dan dibiarkan selama 60 menit. Setelah itu lempeng tersebut diangkat dan dikeluarkan. Selanjutnya media diinkubasi pada suhu $37^{\circ} \mathrm{C}$ selama 1 x 24 jam (bakteri) dan suhu kamar selama $3 \mathrm{x}$ 24 jam (jamur).

\section{b. Difusi Agar}

Dibuat medium base layer, ditambahkan suspensi mikroba dalam medium seed layer hingga homogeny kemudian dimasukkan tiga pencadang tiap cawan petri. Perasan belimbing tanah kosentrasi 25\%, 50\% dan $75 \%$ dimasukkan kedalam pencadang sebanyak $0,3 \mathrm{ml}$ masing-masing kosentrasi.
Cawan petri diinkubasi pada suhu $37^{\circ} \mathrm{C}$ selama $1 \times 24$ jam (bakteri) dan suhu kamar selama $3 \times 24$ jam (jamur).

\section{HASIL PENELITIAN}

\section{Hasil ekstraksi Belimbing tanah}

\section{(Oxalis corniculata L.)}

Belimbing tanah (Oxalis corniculata L.) sebanyak 100 gram dengan metode maserasi menggunakan etanol 96\% diperoleh 15 gram ekstrak etanol kering. Dengan 10 gram partisi ekstrak etanol kering metode padat cair diperoleh 6 gram ekstrak nheksana, 2,5 gram ekstrak dietil eter dan 0,5 gram residu.

\section{Pemisahan koimponen kimia} secara kromatografi lapis tipis

Pemisahan kompoinen kimia ekstrak dietil eter belimbing tanah (Oxalis corniculata L.) secara kromatografi lapis tipis menggunakan eluen $n$-heksan : etil asetat (2:1). Pada penampak bercak UV $254 \mathrm{~nm}$ diperoleh 5 bercak, pada penampak bercak lampu UV 366 nm memperlihatkan 8 bercak dan pada penampak bercak dengan menggunakan $\mathrm{H}_{2} \mathrm{SO}_{4} \quad 10 \%$ diperoleh 5 bercak terlihat pada table 1 gambar 2 . 
Tabel 1. Hasil pemisahan senyawa ekstrak dietil eter belimbing tanah (Oxalis corniculata L.) secara Kromatografi Lapis Tipis

\begin{tabular}{|c|c|c|c|c|c|c|}
\hline \multirow{3}{*}{ Bercak } & \multicolumn{6}{|c|}{ Rf dan Warna Bercak } \\
\hline & \multicolumn{2}{|c|}{ UV 254} & \multicolumn{2}{|c|}{ UV 366} & \multicolumn{2}{|c|}{$\mathrm{H}_{2} \mathrm{SO}_{4} 10 \%$} \\
\hline & $\mathbf{R f}$ & Warna & $\mathbf{R f}$ & Warna & Rf & Warna \\
\hline 1. & 0,89 & Hijau muda & 0,89 & Biru muda & 0,89 & Coklat \\
\hline 2. & 0,82 & Hijau muda & 0,82 & Ungu & 0,82 & Coklat \\
\hline 3. & 0,74 & Hijau & 0,74 & Ungu & 0,74 & Coklat \\
\hline 4. & 0,65 & Hijau & 0,65 & Ungu & 0,65 & Coklat \\
\hline 5. & 0,45 & Hijau muda & 0,61 & Merah muda & 0,45 & Putih \\
\hline 6. & - & - & 0,52 & Merah muda & - & - \\
\hline 7. & - & - & 0,45 & Ungu & - & - \\
\hline 8. & - & - & 0,33 & Merah muda & - & - \\
\hline
\end{tabular}

3. Pengujian skrining antimikroba

Skrining aktivitas antimikroba secara KLTBioautografi ekstrak etanol, $\mathrm{n}$ heksan, dietil eter dan residu belimbing tanah (Oxalis corniculata L.) terhadap beberapa mikroba uji diantaranya yaitu Salmonella thypi, Staphylococcus aureus, Streptococcus mutans, Streptococcus epidermidis, Vibrio sp, Escherichia coli, dan Candida albicans, maka diperoleh hasil bahwa ekstrak dietil eter menunjukkan aktivitas menghambat terhadap semua mikroba yang diujikan. Terlihat pada tabel 2 gambar 3.

Tabel 2. Hasil skrining aktivitas antimikroba ekstrak belimbing tanah (Oxalis corniculata L.) terhadap beberapa mikroba uji secara KLT-Bioautografi

\begin{tabular}{ccccccccc}
\hline \multirow{2}{*}{ No } & \multirow{2}{*}{ Ekstrak } & \multicolumn{8}{c}{ Rf Mikroba Uji } \\
\cline { 3 - 9 } & SA & ST & SM & SE & EC & Vsp & CA \\
\hline 1 & Etanol & - & - & - & - & - & - & - \\
2 & n-heksan & - & - & - & - & - & - & - \\
3 & Dietil eter & 0.45 & 0.45 & 0.45 & 0.45 & 0.45 & 0.45 & 0.45 \\
4 & Residu & - & - & - & - & - & - & - \\
\hline
\end{tabular}

\section{Keterangan :}

SM = Streptococcus mutans

ST $\quad=$ Salmonella typhi

SE = Staphylococcus epidermidis

$\mathrm{CA} \quad=$ Candida albicans

$\begin{array}{ll}\text { EC } & =\text { Escherichia coli } \\ \text { SA } & =\text { Staphylococcus aureus } \\ \text { VC } & =\text { Vibrio } s p \\ - & =\text { Tidak menghambat mikroba uji }\end{array}$


Skrining Aktivitas Antimikroba Ekstrak Herba Belimbing Tanah Secara KLT-Bioautografi Dan Difusi Agar

4. Hasil pengujian aktivitas pertumbuhan mikroba Salmonella antimikroba secara KLT- thypi, Staphylococcus aureus, bioautografi

Streptococcus mutans,

Pengujian aktivitas ekstrak Streptococcus epidermidis, Vibrio dietil eter belimbing tanah (Oxalis corniculata L.) secara sp, Escherichia coli, dan Candida KLT-Bioautografi bercak albicans terlihat pada tabel 3 gambar 4

dengan nilai $\operatorname{Rf} 0.45$ menghambat

Tabel 3. Hasil pengujian aktivitas antimikroba ekstrak dietil eter belimbing tanah (Oxalis corniculata L.) secara KLT-Bioautografi

\begin{tabular}{ccccc}
\hline \multirow{2}{*}{ Rf } & \multicolumn{2}{c}{ Warna pada penampak bercak } & \multirow{2}{*}{ Mikroba uji } \\
\cline { 2 - 4 } & UV 254 & UV 366 & $\mathbf{H}_{2} \mathbf{S O}_{4}$ & \\
\hline 0.45 & Hijau muda & Ungu & Putih & SA, VC, EC, SM, ST, SE, CA \\
\hline
\end{tabular}

Keterangan :

\begin{tabular}{|c|c|c|c|}
\hline $\begin{array}{l}\text { SM } \\
\text { ST } \\
\text { SE }\end{array}$ & $\begin{array}{l}=\text { Streptococcus mutans } \\
=\text { Salmonella typhi } \\
=\text { Staphylococcus epidermidis }\end{array}$ & $\begin{array}{l}\text { EC } \\
\text { SA } \\
\text { VC }\end{array}$ & $\begin{array}{l}=\text { Escherichia coli } \\
=\text { Staphylococcus aureus } \\
=\text { Vibrio } s p\end{array}$ \\
\hline
\end{tabular}

5. Hasil pengujian aktivitas antimikroba secara difusi agar

Pengujian aktivitas perasan belimbing tanah (Oxalis corniculata L.) secara difusi agar pada kosentrasi $25 \%$, 50\% dan $75 \%$ menghambat pertumbuhan mikroba Salmonella thypi, Staphylococcus aureus, Streptococcus mutans, Streptococcus epidermidis, Vibrio sp, Escherichia coli, dan Candida albicans terlihat pada tabel 4 gambar 5 .

Tabel 4. Diameter rata-rata pengujian aktivitas antimikroba perasan belimbing tanah (Oxalis corniculata L.) secara difusi agar

\begin{tabular}{|c|c|c|c|c|c|}
\hline \multirow[t]{2}{*}{ No } & \multirow[t]{2}{*}{ Mikroba Uji } & \multicolumn{3}{|c|}{$\begin{array}{c}\text { Diameter Rata-Rata Kosentrasi } \\
\text { Sampel }\end{array}$} & \multirow{2}{*}{$\begin{array}{l}\text { Rata-Rata } \\
(\mathbf{m m})\end{array}$} \\
\hline & & $25 \%$ & $50 \%$ & $75 \%$ & \\
\hline 1 & Salmonella thypi & 19.66 & 24.66 & 29.66 & 24.66 \\
\hline 2 & Staphilococcus aureus & 10.00 & 12.00 & 20.00 & 13.00 \\
\hline 3 & Eschericia coli & 18.00 & 20.33 & 21.66 & 19.99 \\
\hline 4 & Vibrio sp & 13.00 & 14.66 & 25.66 & 17.77 \\
\hline 5 & Streptococcus mutans & 13.00 & 15.00 & 17.00 & 15.00 \\
\hline 6 & Candida albicans & 13.00 & 15.00 & 17.00 & 15.00 \\
\hline
\end{tabular}


Skrining Aktivitas Antimikroba Ekstrak Herba Belimbing Tanah Secara KLT-Bioautografi Dan Difusi Agar

\section{PEMBAHASAN}

Belimbing tanah merupakan salah satu tumbuhan obat asli Indonesia karena tumbuhan ini secara empiris digunakan oleh masyarakat kabupaten Mamuju sebagai obat flu, batuk dan belum banyak diketahui masyarakat luas. Menurut Setiawan (2006), tumbuhan ini dapat mengaobati penyakit demam, flu, diare, radang hati, radang tenggorokan, infeksi saluran kencing, terlambat haid, hipertensi dan neurasthenia. Tumbuhan belimbing tanah sebanyak 50 gram dengan metode maserasi diperoleh 15 gram ekstrak etanol, 6 gram ekstrak nheksana, 2,5 gram ekstrak dietil eter dan 0,5 gram residu.

Pemisahan kompoinen kimia ekstrak dietil eter belimbing tanah (Oxalis corniculata L.) secara kromatografi lapis tipis menggunakan eluen n-heksan : etil asetat (2:1). Pada penampak bercak UV $254 \mathrm{~nm}$ diperoleh 5 bercak, pada penampak bercak lampu UV $366 \mathrm{~nm}$ memperlihatkan 8 bercak dan pada penampak bercak dengan menggunakan $\mathrm{H}_{2} \mathrm{SO}_{4} 10 \%$ diperoleh 5 bercak.

Hasil skrining dan pengujian aktivitas antimikroba secara KLTBioautografi menunjukkan bahwa ekstrak dietil eter yang memberikan penghambatan pertumbuhan mikroba uji dengan nilai $\mathrm{Rf}$ 0,45 terhadap bakteri Staphylococcus epidermidis, Streptococcus mutans, Staphylococcus aureus, Salmonella thypi, Vibrio sp, Escherichia coli, jamur Candida albicans dengan melihat zona bening pada permukaan medium tempat berdifusi bercak dari kromatogram yang dapat menghambat 7 mikroba uji, hal ini disebabkan adanya komponen kimia aktif pada ekstrak yang dapat menghambat pertumbuhan mikroba tersebut.

Pengujian aktivitas perasan belimbing tanah (Oxalis corniculata L.) secara difusi agar menghambat pertumbuhan mikaoba Staphylococcus epidermidis, Streptococcus mutans, Staphylococcus aureus, Salmonella thypi, Vibrio sp, Escherichia coli, dan Candida albicans, dengan diameter rata-rata penghambatan pertumbuhan mikroba paling besar adalah terhadap bakteri Salmonella thypi pada kosentrasi $25 \%=19.66 \mathrm{~mm}, 50 \%=$ $24.66 \mathrm{~mm}$ dan $75 \%=29.66 \mathrm{~mm}$.

\section{KESIMPULAN}

1. Ekstrak dietil eter belimbing tanah (Oxalis corniculata L.) secara KLTBioautografi menghambat pertumbuhan mikroba uji 
Skrining Aktivitas Antimikroba Ekstrak Herba Belimbing Tanah Secara KLT-Bioautografi Dan Difusi Agar

Escherichia coli, Salmonella typhi,

Staphylococcus

aureus,

Streptococcus

mutans,

Streptococcus epidermis, Vibrio sp dan Candida albicans dengan nilai $\mathrm{Rf} 0,45$.

2. Perasan belimbing tanah (Oxalis corniculata L.) secara difusi agar menghambat pertumbuhan mikroba uji Escherichia coli, Salmonella typhi, Staphylococcus aureus, Streptococcus mutans, Streptococcus epidermis, Vibrio sp dan Candida albicans dengan diameter rata-rata penghambatan mikroba terhadap bakteri Salmonella thypi yang paling besar yaitu pada kosentrasi $25 \%=19.66$ $\mathrm{mm}, 50 \%=24.66 \mathrm{~mm}$ dan $75 \%=$ $29.66 \mathrm{~mm}$.

\section{DAFTAR PUSTAKA}

Anonim, 2010. Plantamor Situs dunia tumbuhan, (Online),(http://ww w.plantamor. com/index. php? plant $=928$, Diakses 5 Februari 2012).

Anonim, 2009. khasanah herba warisan
(Online), (http://www.melur.c om/myherba.asp ? plant id=172\&cat=HERBA. $D$ iakses 5 Februari 2012).

Betina,V.,1972, Pharmaceotical Application Of Thin Layer And Paper Chromatography, Amsterdam. Hal.503-507

Djide, N., dkk., 2006, Analisis Mikrobiologi

Farmasi, Laboratorium

Mikrobiologi Farmasi dan Bioteknologi Farmasi, Fakultas MIPA, Universitas Hasanudin, Makassar.

Ditjen POM, 1986, Sediaan Galenika. Departemen Kesehatan Republik Indonesia, Jakarta. 10-15.

Ganiswarna, S.G. 1995. Farmakologi dan Terapi, Edisi 4. Badan Farmakologi Fakultas Kedokteran UI: Jakarta.

Steenis, Van.C.G.G.J. dkk. 2008. Flora. PT. Pradnya Paramita: Jakarta .

Tobo, F., Mufidah, taebe, B dan Mahmud, I. 2001. Buku Pegangan Laboratorium Fitokimia I. Laboratorium Fitokimia Jurusan Farmasi, FMIPA. Universitas Hasanuddin: Makassar. 